\title{
Daily feeding activity of Bryconamericus microcephalus (Characiformes, Characidae) from Córrego Andorinha, Ilha Grande - RJ
}

\author{
Mazzoni, R.* and Rezende, $C F$ * \\ Laboratório de Ecologia de Peixes, Departamento de Ecologia, \\ Instituto de Biologia Roberto Alcântara Gomes, Universidade do Estado do Rio de Janeiro - UERJ, \\ Av. São Francisco Xavier, 524, Maracanã, CEP 20550-013, Rio de Janeiro, RJ, Brazil \\ *e-mail: mazzoni@uerj.br, carla.fr@terra.com.br
}

Received July 20, 2007 - Accepted February 20, 2008 - Distributed May 31, 2009

(With 2 figures)

\begin{abstract}
The present study was conducted at the Córrego Andorinha on the eastern slope of Ilha Grande and aimed to determine the alimentary daily rhythm of Bryconamericus microcephalus. Fishes were sampled at a 4 hours interval over a 24 hours period during winter 2002 and summer 2003. Gut fullness was determined according to a numerical scale ranging from 0 (empty gut) to 3 (full gut). No differences were registered for the daily ration estimates between seasons. It is concluded that B. microcephalus is a diurnal feeding species, as the high values of gut fullness occurred between 11:00 AM and 3:00 PM.
\end{abstract}

Keywords: stream-dwelling fish, trophic ecology, Mata Altântica, costal stream.

\section{Ritmo diário da alimentação de Bryconamericus microcephalus do córrego Andorinha, Ilha Grande, Rio de Janeiro}

\begin{abstract}
Resumo
O presente estudo foi desenvolvido no Córrego Andorinha, localizado na vertente continental da Ilha Grande e teve como objetivo avaliar o ritmo diário da alimentação de Bryconamericus microcephalus. Os peixes foram amostrados ao longo de 24 horas a intervalos de 4 horas, no inverno de 2002 e no verão de 2003. O grau de repleção estomacal foi determinado de acordo com uma escala numérica que variou de 0 (estômago vazio) a 3 (estômago cheio). Não foram registradas diferenças para o ritmo diário de alimentação, quando consideradas as duas estações estudadas. Concluímos que B. microcephalus tem hábito alimentar diurno com os maiores valores de graus de repleção entre 11:00 e 15:00 horas.
\end{abstract}

Palavras-chave: peixes de riacho, ecologia trófica, Mata Atlântica, riacho costeiro.

\section{Introduction}

The use of environmental resources by fish is strongly influenced by temporal changes in the environment (Wootton, 1998). Among such environmental changes, seasonal changes on the photoperiod are the most important ones, but in tropical regions, these changes are negligible although daily changes are the most important (Gerking, 1994).

Fish diet usually changes throughout life because of the morphological changes that accompany growth, but superimposed on ontogenetic changes, there may be circadian changes in feeding activity (Wootton, 1990). Searching, ingestion, digestion and resting compose the main parts of a fish circadian feeding cycle and are, normally, determined by photoperiod (Zavala-Camin, 1992). Despite the scarce information concerning daily feeding patterns of freshwater fishes from tropical areas, this is an important aspect of fish life-history strategy (Gerking, 1994) as it informs on the trophic interactions between organisms in a community (Darbyson et al., 2003).

Foraging behaviour is constrained by physiological requirements and the circadian rhythm is one of the most important cues for the daily pattern of foraging (Dill, 1983; Rabelo and Araújo-Lima, 2002). The circadian pattern of activity is among the most conservative behaviour in animals and, in the case of fishes, varies according to taxonomic groups; for example, Characiformes are diurnal species but Siluriformes are crepuscular ones (e.g. Sabino and Castro, 1990; Soares-Porto, 1994).

Bryconamericus microcephalus (Miranda-Ribeiro) is the most abundant Characiform in Córrego Andorinha (Ilha Grande, Rio de Janeiro). Reproductive studies revealed that spawning occurs between July and February 
with a reproductive peak between September and December (Mazzoni and Silva, 2006). B. microcephalus it is an insectivorous species foraging both on autochthonous and allochthonous insects but the relative abundance of each resource is seasonally determined (Rezende and Mazzoni, 2003; Rezende and Mazzoni, 2006b). Considering only the allochthonous insects consumed by the species, an ontogenetic variation on prey preference were detected (Rezende and Mazzoni, 2006a).

In the present study we aimed to determine the circadian feeding rhythm of $B$. microcephalus following the hypothesis postulated by Sabino and Castro (1990) that it is a diurnal species as are many other Characidian species.

\section{Material and Methods}

\subsection{Study area}

Córrego Andorinha is a small ( $\approx 20 \mathrm{~km}$ long), low altitude ( $<150 \mathrm{~m}$ a.s.1.) stream flowing across the eastern slope of Ilha Grande $\left(23^{\circ} 05^{\prime} ; 23^{\circ} 15^{\prime} \mathrm{S}\right.$ and $44^{\circ} 06$; and $44^{\circ} 23^{\prime} \mathrm{W}$ ) towards the Atlantic Ocean (Angra dos Reis, southeast Brazil). In Córrego Andorinha, water discharge is seasonally determined by rainfall $(\sim 1,500 \mathrm{~mm}$ per year) that is more abundant during summer (November-January) which may accentuate discharge variations. Moreover, tropical storms ( $>60 \mathrm{~mm}$ in a day) occur throughout the year and may increase the water level several-fold but a return to base-flow conditions occurs within the same day. The sunlight daily cycle is seasonally determined but, according to its latitudinal position, the photoperiod did not vary for more than 3 hours between June (winter solstice) and February (summer solstice) (Figure 1).The study site was a canopy stretch ( $\approx 80 \mathrm{~m}$ long $)$ and comprised intercalated runs and lateral pools with sand, gravel and mud substrata.

\subsection{Sampling Procedure}

Fishes were sampled six times, at a 4 hours interval over a 24 hours period (3:00, 7:00, 11:00 AM and 3:00,

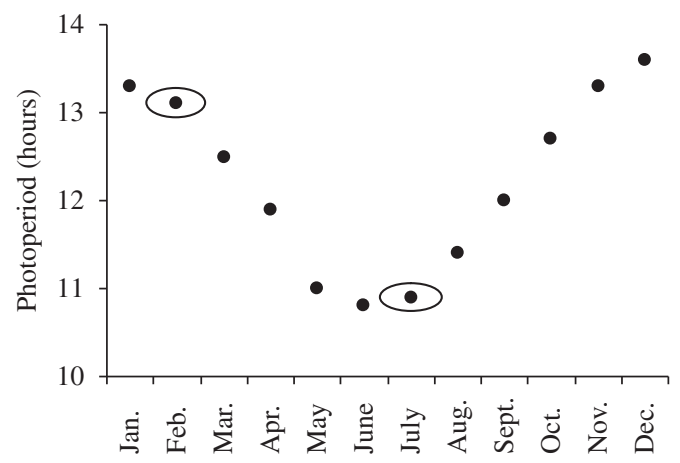

Figure 1. Seasonal variation of photoperiod in the study area $\left(23^{\circ} 05^{\prime} ; 23^{\circ} 15^{\prime} \mathrm{S}\right.$ and $\left.44^{\circ} 06 ; 44^{\circ} 23^{\prime} \mathrm{W}\right)$. Studied months are marked with circles. Data were obtained from www.on.br.
7:00 and 11:00 PM) in winter (July / $2002=11$ hours photoperiod) and summer (February $2003=13$ hours photoperiod) of 2003. At each sampling time waiting nets $(10 \mathrm{~mm}$ mesh size) were exposed for $\approx 30$ minutes while seines and picarés ( $5 \mathrm{~mm}$ mesh size) were operated in the areas outside the waiting nets influence. Ten individuals were randomly selected from each sample and immediately frozen $\left(-30^{\circ} \mathrm{C}\right)$ until analysis. Thereafter, in the laboratory, fishes were measured (SL, cm to the nearest $\mathrm{mm}$ ), weighed (Wt, gr) and eviscerated. Gut weight $(\mathrm{Wg})$ was registered to the nearest $0.01 \mathrm{~g}$; gut content was removed, separated from mucus and measured (wet mass of gut content; $\mathrm{Wc}$ ) to the nearest $0.01 \mathrm{~g}$.

\subsection{Data Analysis}

The repletion degree (RD) of each gut was estimated according to the following model: $\mathrm{RD}=100 \mathrm{Wc} / \mathrm{Wt}$. where: $\mathrm{Wt}=$ fish weight and $\mathrm{Wc}=$ gut content weight. Gut fullness index (GFI) was determined according to a numerical scale proposed by Hahn et al. (1999) and Moreira and Zuanon (2002) as follows: 0) $\mathrm{RD}=0 \%$; 1 ) $\mathrm{RD}>0 \%<25 \%$; 2) $\mathrm{RD}>25 \%<75 \%$; and 3) $\mathrm{RD}>75 \%$. Daily activity estimates were based on the percentage of individuals in each GFI for each sampling time for both summer and winter data.

\section{Results}

A total of 60 individuals, ranging from 1.5 to $7.2 \mathrm{~cm}$ (Table 1), were collected at each season totalling 120 individuals during the whole study period. Previous analysis were done separately to the summer and winter seasons, but visual inspection of graphical results and $\chi^{2}$ test $\left(\chi^{2}=1.53 ; \mathrm{df}=3 ; \mathrm{p}=0.67\right)$ did not show seasonal differences for the daily variations of Gut Fullness Index (GFI) between seasons. Moreover, photoperiod differences between winter and summer did not exceeded 3 hours, thus, data collections (winter and summer) were grouped to final analysis.

Although feeding activity was registered throughout the day (GFI > 1), frequency distribution of GFI

Table 1. Maximum (Max.), minimum (Min.) and mean standard length (SL, cm) of Bryconamericus microcephalus sampled during 24 hours at a 4 hours interval in the winter of 2002 and summer of 2003.

\begin{tabular}{|c|c|c|c|c|c|c|}
\hline \multirow[t]{3}{*}{ SL } & \multicolumn{6}{|c|}{ Winter } \\
\hline & 3:00 & $7: 00$ & 11:00 & 3:00 & 7:00 & 11:00 \\
\hline & \multicolumn{3}{|c|}{ AM } & \multicolumn{3}{|c|}{ PM } \\
\hline Max. & 7.0 & 7.2 & 6.8 & 7.0 & 7.0 & 6.6 \\
\hline Min. & 1.8 & 2.1 & 1.5 & 1.8 & 1.9 & 1.9 \\
\hline Mean & 4.9 & 4.6 & 5.2 & 4.7 & 4.9 & 4.5 \\
\hline SL & \multicolumn{6}{|c|}{ Summer } \\
\hline Max. & 7.2 & 7.0 & 6.8 & 7.1 & 7.0 & 6.8 \\
\hline Min. & 1.8 & 1.5 & 2.1 & 1.8 & 1.9 & 1.8 \\
\hline Mean & 5.1 & 4.7 & 5.2 & 5.2 & 4.9 & 4.8 \\
\hline
\end{tabular}


values showed that $B$. microcephalus presented a temporal pattern of feeding cycle. Between 7:00 PM and 7:00 AM, low feeding activity was registered, GFI was predominantly 0 and / or 1 . Specimens with GFI between 2 and 3, which seems a high feeding activity, were numerous between 11:00 AM and 3:00 PM, suggesting that B. microcephalus is a diurnal feeder and presented the higher values of GFI during the high intensity of solar light incidence (Figure 2).

\section{Discussion}

Bryconamericus species have been classified in different trophic categories and vary between omnivory, exploring particularly autochthonous and allochthonous insects as well as algae (Uieda et al., 1997; Casatti and Castro, 1998), and insectivory behaviour (Uieda et al., 1987; Rezende and Mazzoni, 2003; Russo et al., 2004). B. microcephalus from Córrego Andorinha (Ilha Grande) can be classified as insectivorous due to the existing registers, alternating the relative importance of the allochthonous and autochtonous items according to the study site and to the season of the year (Rezende and Mazzoni, 2006a and b).

Preliminary analysis carried out to detect seasonal differences in the alimentary daily rhythm did not indicate any differences, probably as a consequence of the small seasonal difference of the photoperiod that, in the study area, does not go over 2 hours and 10 minutes (low latitude function of the study area). Besides this, it is known that the activity rhythm is controlled through endogenous controllers, which many times outdo environmental cues (Meisel et al., 2003). In the case of B. microcephalus, this last fact may be reinforced by the small seasonal variation of the photoperiod and, because of this, it determines the inexistence of different seasonal patterns of the activity.

Although an alimentary activity peak was identified, occurrence of stomachs with GFI $\geq 1$ was observed during the whole daily cycle ( 24 hours), suggesting that even on a smaller scale, B. microcephalus forages all through the day. According to Hahn et al. (1999), many fish species continuously feed or, at least, have a long alimentary daily activity period and this characteristic was observed in the studied species. In a study of the daily alimentary rhythm of Astyanax bimaculatus, a Characidae species, Lóbon-Cerviá and Bennemann (2000) registered a foraging activity during all the daily cycle, having a greater activity during the diurnal period, indicating results similar to ours.

Individuals of B. microcephalus move in big groups, although in a disorganized way. They are pelagic and reophilic, spending long periods of time swimming actively against the current. They occupy the entire water column, exploring from the surface to the bottom, but they are predominantly found in the middle area of the water column. They feed on arthropods and allochthonous matter on drift (Rezende and Mazzoni, 2003). This be- haviour shows the importance of sight as the main mechanism for predation and explains, partially, the diurnal period as being the one with greater alimentary activity and predator behaviour, which remains active for long periods of the day and uses sight as the main sensory organ for feeding purposes (Hyatt, 1979; Gerking, 1994). According to Gerking (1994), an important example of the importance of sight for predatory species is the large


Figure 2. Daily variation of the Gut Fullness Index (GFI) of Bryconamericus microcephalus from the Córrego Andorinha. 
number of zooplanktivores species feeding selectively on larger zooplankton over smaller ones.

We conclude that whereas $B$. microcephalus presented a prolonged feeding activity during the 24 hours inter$\mathrm{val}$, the main activity was registered between 11:00 AM and 3:00 PM during the high intensity of solar light incidence. This conclusion should allow us to classify the species as a diurnal feeder like many other Characins.

Acknowledgements - This study is part of the Master Thesis of the senior author (CFR). It was supported by $\mathrm{CNPq}$ project n. APQ-2002-479426/01-5 and by individual grants to CFR - FAPERJ n. E-26/151.406/2003 and to RM - CNPq n. 302628/2002-9. Thanks are due to the staff of Laboratório de Ecologia de Peixes / UERJ for help in the field and laboratory and to Chiara Mazzoni for the English translation.

\section{References}

CASATTI, L. and CASTRO, RMC., 1998. A fish community of the São Francisco River headwater riffles, southeastern Brazil. Ichthyological Explorations of Freshwaters, vol. 9, no. 3, p. 229-242.

DARBYSON, E., SWAIN, DP., CHABOT, D. and CASTONGUAY, M., 2003. Diel variation in feeding rate and prey composition of herring and mackerel in the southern Gulf of St. Lawrence. Journal of Fish Biology, vol. 63, no. 5, p. $1235-1257$.

DILL, LM., 1983. Adaptive flexibility in the foraging behavior of fishes. Canadian Journal of Fisheries and Aquatic Sciences, vol. 40, p. 398-408.

GERKING, SD., 1994. Feeding ecology of fish. San Diego: Academic Press. 416p.

HAHN, NS., LOUREIRO, VE. and DELARIVA, RL., 1999. Atividade alimentar da curvina Plagioscion squamosissimus (Heckel, 1840) (Perciformes, Sciaenidae) no rio Paraná. Acta Scienitiarum, vol. 21, no. 3, p. 309-314.

HYATT, KD., 1979. Feeding strategy. In HOAR, WS., RANDALL, DJ. and BRETT, JR. (Eds.). Fish physiology. New York: Academic Press. p. 71-120.

LOBÓN-CERVIÀ, J. and BENNEMANN, S., 2000. Temporal trophic shifts and feeding diversity in two sympatric, neotropical, omnivorous fishes: Astyanax bimaculatus and Pimelodus maculatus in Rio Tibagi (Paraná, Southern Brazil). Archives Fur Hydrobiologie, vol. 149, no. 2, p. 205-306.

MAZZONI, R. and SILVA, APF., 2006. Aspectos da história de vida de Bryconamericus microcephalus (Miranda Ribeiro) (Characiformes, Characidae) de um riacho costeiro de Mata Atlântica, Ilha Grande, Rio de Janeiro, Brasil. Revista Brasileira de Zoologia, vol. 23, no. 1, p. 228-233.
MEISEL, DV., BYRNE, RA., KUBA, M., GRIEBEL, U. and MATHER, JA., 2003. Circadian rhythms in Octopus vulgaris. Berliner Paläobiologische Abhadlungen, vol. 3, p. 171-177.

MOREIRA, SS. and ZUANON, J., 2002. Dieta de Retroculus lapidifer (Perciformes: Cichilidae), um peixe reofílico do Rio Araguaia, Estado de Tocantins, Brasil. Acta Amazonica, vol. 32, no. 4, p. 691-705.

RABELO, H. and ARAÚJO LIMA, CARM., 2002. A dieta e o consumo diário de alimento de Cichla monoculus na Amazônia Central. Acta Amazonica, vol. 32, no. 4, p. 707-724.

REZENDE, CF. and MAZZONI, R., 2003. Aspectos da alimentação de Bryconamericus microcephalus (Characiformes, Tetragonopterinae) no Córrego Andorinha, Ilha Grande - RJ. Biota Neotropica, vol. 3, no. 1, p. 1-6.

REZENDE, CF. and MAZZONI, R., 2006a. Disponibilidade e uso de recursos alóctones por Bryconamericus microcephalus (Miranda-Ribeiro) (Actinipterygii-Characidae), no córrego Andorinha, Ilha Grande, Rio de Janeiro, Brasil. Revista Brasileira de Zoologia, vol. 23, no. 1, p. 218-222.

REZENDE, CF. and MAZZONI, R., 2006b. Contribuição da matéria autóctone e alóctone para a dieta de Bryconamericus microcephalus (Miranda-Ribeiro) (Actinipterygii-Characidae), em dois trechos de um riacho de Mata Atlântica, Rio de Janeiro, Brasil. Revista Brasileira de Zoologia, vol. 23, no. 1, p. 58-63.

RUSSO, MR., HAHN, NS. and PAVANELLI, CS., 2004. Resource partitioning between two species of Bryconamericus Eigenmann, 1907 from the Iguaçu river basin, Brazil. Acta Scientiarum, vol. 26, no. 4, p. 431-436.

SABINO, J. and CASTRO, CMR., 1990. Alimentação, período de atividade e distribuição espacial dos peixes de um riacho da floresta Atlântica (Sudeste do Brasil). Revista Brasileira de Biologia = Brazilian Journal of Biology, vol. 50, no. 1, p. 23-26.

SOARES-PORTO, LM., 1994. Dieta e ciclo diurno de atividade alimentar de Pimelodella lateristriga (Müller e Troschel, 1849) (Siluroidei, Pimelodidae). Revista Brasileira de Biologia = Brazilian Journal of Biology, vol. 54, no. 3, p. 451-458.

UIEDA, VS., UIEDA, W., CARNEIRO, BC., SILVEIRA, SA., MELO, MLS. and DORNELAS, RH., 1987. Rede alimentar em duas comunidades de um riacho de água doce. An. Semin. Ci. Fiube, vol. 1, p. 97-113.

UIEDA, VS., BUZZATO, P. and KIKUCHI, RM., 1997. Partilha de recursos alimentares em peixes em um riacho de serra do Sudeste do Brasil. Anais Academia Brasileira de Ciencias, vol. 69 , no. 2 , p. $243-252$.

ZAVALA-CAMIN, LA., 1992. Alimentação de peixes. In AGOSTINHO, A. and BENEDITO-CECÍlLIO, E. (Eds). Situação atual e perspectivas da ictiologia no Brasil. Maringá: Editora UEM. p. 14-18.

WOOTTON, RJ., 1998. Ecology of teleost fishes. Boston: Kluwer Academic Publisheres. 396p. 